\title{
Efeito da suplementação alimentar sobre as características produtivas e reprodutivas de Apis mellifera Linnaeus, 1758
}

\author{
Tânia Patrícia Schafaschek ${ }^{1,2}$ \\ Marília Terezinha Sangoi Padilha ${ }^{3 *}$ \\ Ione Iolanda dos Santos ${ }^{3}$ \\ José Carlos Fiad Padilha ${ }^{3}$ \\ Fabio Eduardo Braga ${ }^{4}$
${ }^{1}$ Empresa de Pesquisa Agropecuária e Extensão Rural de Santa Catarina SA - EPAGRI ${ }^{2}$ PPG em Agroecossistemas, Universidade Federal de Santa Catarina (UFSC) CEP 88040-900, Florianópolis - SC, Brasil ${ }^{4}$ Itaspurg do Brasil Inspeções Agrícolas, Itajaí - SC, Brasil *Autor para correspondência mariliap@mbox1.ufsc.br \\ ${ }^{3}$ Departamento de Zootecnia da UFSC, Rodovia Admar Gonzaga, 1346, Caixa Postal 476
}

\section{Resumo}

O objetivo deste trabalho foi avaliar o desempenho de colméias de Apis mellifera submetidas ou não a suplementação energético-protéica, entre maio e dezembro de 2003, num apiário em Ituporanga/SC. As colméias foram distribuídas aleatoriamente, sendo que cinco foram suplementadas com xarope de açúcar invertido e um componente protéico-vitamínico (Promotor $\mathrm{L}^{\circledR}$ ) e as outras cinco colméias não receberam suplementação. Avaliou-se a área com ovos e larvas, a área com pupa, a área com pólen e a área com mel. Observaram-se diferenças significativas entre os tratamentos para todos os parâmetros analisados. Os maiores valores para as áreas de ovo e larva e de pupa das colméias suplementadas foram obtidos no período de maior disponibilidade de alimentos na natureza. A área de pólen das colméias não suplementadas apresentou-se maior a partir de junho, sendo que as suplementadas apresentaram maior armazenamento de pólen apenas na época em que a disponibilidade deste na natureza era menor e as condições climáticas menos propícias para a coleta e desenvolvimento das colméias. No final do período, as colméias com alimentação suplementar apresentaram maior área de mel. A suplementação energético-protéica interferiu no armazenamento de alimento pelas abelhas, mas não proporcionou a antecipação do desenvolvimento das colméias.

Unitermos: apicultura, pólen, Promotor $\mathrm{L}^{\circledR}$, manejo de colméias, abelhas

\section{Abstract}

Effect of food supplementation on the productive and reproductive characteristics of Apis mellifera Linnaeus, 1758. The objective of this study was to evaluate the performance of Apis mellifera beehives submitted or unsubmitted to an energetic-protein supplementation. The experiment was realized from May to December 2003, in an apiary in Ituporanga (SC). The beehives were randomly distributed in the experimental area. The energetic-protein supplementation consisted of the syrup of reversed sugar plus a vitamin-protein called L 
Promoter ${ }^{\circledR}$ and it was applied to five beehives; five other beehives did not receive the supplementation. Data on the number of eggs, larva, pupae, pollen and honey area were evaluated. Significant differences were observed between the treatments for each parameter analyzed. Beehives with the energetic-protein supplementation presented higher values for eggs, larva and pupae when there was little food available in the environment. Beehives with no supplementation presented an increase in pollen area starting in June, while the supplied beehives presented a greater pollen storage when the period of available pollen in nature was decreased and the climatic conditions were not favorable for the harvesting and development of beehives. The energetic-protein supplementation improved the storage of food by the bees, but did not bring forward the development of their beehives.

Key words: beekeeping, pollen, L Promoter $^{\circledR}$, beehives management, bees

\section{Introdução}

A suplementação alimentar energético-protéica pode ser adotada para estimular a colméia, antecipando o desenvolvimento da mesma. Desta forma, ao iniciar a oferta de néctar na natureza, a colméia já terá atingido o seu pico populacional, realizando uma coleta mais eficiente, o que implicará positivamente na produção de mel (Salomé, 2002).

O estímulo primário para a postura em uma colméia provém da oferta de carboidratos presentes no néctar, no mel ou no açúcar, porém, as larvas e pupas somente se desenvolverão mediante a oferta de uma alimentação balanceada em energia e proteína. Portanto, logo após o estímulo para o início da postura, é necessária a oferta de pólen ou de um suplemento equivalente para o desenvolvimento das larvas (Silva e Silva, 1985).

Alternativas de suplementação alimentar, principalmente em períodos de escassez natural de pólen ou períodos em que este se torne escasso devido a alguma adversidade climática, são importantes para que não ocorram bruscas reduções na produção de mel. Pequenas flutuações diárias na quantidade de alimento coletado provavelmente pouco influenciam no desenvolvimento da prole, no entanto, flutuações maiores podem ter um efeito considerável (Salomé, 2002). Carências de pólen podem ocorrer em qualquer época do ano, devido a fatores do ambiente (Doull, 1975) ou quando as abelhas estão freqüentando plantas que produzem muito néctar e pouco pólen (Johansson e Johansson, 1977). Deficiências de néctar podem ocorrer quando há um longo período com precipitações intensas e contínuas, em que as flores perdem o néctar, ou quando ocorrem longos períodos com baixas temperaturas em que as abelhas praticamente paralisam suas atividades e não coletam alimentos (Lengler et al., 2000). Ainda podem ocorrer, quando as abelhas estão polinizando culturas que produzem muito pólen e pouco néctar, ou quando falha uma florada (Chaud Netto, 1992).

A suplementação alimentar, no entanto, não deve ser executada isoladamente no apiário, mas sim como uma etapa do manejo produtivo. A alimentação dos enxames, além de equilibrada, deve ser feita considerando, entre outros aspectos, as condições climáticas da região (variáveis ano a ano), pois a ausência ou pouca oferta de florada por ocasião do aumento das populações provocará a mortalidade ou diminuição da população do enxame estimulado (Salomé, 2002).

O conhecimento da influência da suplementação alimentar sobre o desenvolvimento das colméias é de extrema importância, pois se sabe que o manejo alimentar é especialmente determinado por estes fatores. As poucas informações existentes a respeito deste tema, principalmente para os diferentes ecossistemas apícolas do Estado de Santa Catarina, geram uma lacuna quanto à decisão do uso ou não da suplementação alimentar e em que época esta deve ser realizada para cada região e finalidade.

Com o objetivo de analisar a influência da suplementação energético-protéica no desenvolvimento de colméias de Apis mellifera Linnaeus, 1758, e suas conseqüências nas características produtivas e reprodutivas das mesmas, realizou-se este experimento.

\section{Material e Métodos}

$\mathrm{O}$ experimento foi realizado em um apiário no município de Ituporanga/SC, região do Alto Vale do Itajaí 
(latitude $27^{\circ} 24^{\prime} 05^{\prime \prime} \mathrm{S}$, longitude $49^{\circ} 36^{\prime} 09^{\prime \prime} \mathrm{W}$ e altitude de $370 \mathrm{~m})$. A vegetação é caracterizada pela presença da Floresta Ombrófila Densa, associada a áreas com atividades agrícolas e vegetação secundária. As principais plantas de importância apícola incluem várias espécies de vassouras como o vassourão-branco (Piptocarpha angustifolia Dusen), vassourão-preto (Piptocarpha cf. tomentosa Baker), a vassoura-branca (Baccharis cf. dracunculifolia DC), a vassoura (Eupatorium sp.), a maria-mole (Senecio brasiliensis Less), a vara-de-foguete (Solidago chilensis Meyen), o sangueiro (Croton celtidifolius Baill), a bracatinga (Mimosa scabrella Bentham), a guabiroba (Campomanesia xanthocarpa Berg), o guamirim (Myrcia rostrata DC), a uva-do-Japão (Hovenia dulcis Thunb), o pessegueiro-bravo (Prunus sellowii Koehn), espécies de citros (Citrus spp.) e a carne-de-vaca (Styrax leprosus Hook. \& Arn.), com a maior porcentagem de plantas em floração e o maior fluxo de néctar verificado no período de setembro a novembro (Salomé, 2002).

Foram avaliadas e selecionadas dez colméias que apresentavam a área ocupada com ovo, larva, pupa, mel e pólen semelhantes, sendo que as rainhas também foram avaliadas para que todas as colméias possuíssem um potencial de postura equiparável, no inicio do experimento. As colméias continham inicialmente, sete favos preenchidos com ovo, larva, pupa, mel e pólen e três favos com cera alveolada nova. Das dez colméias, cinco foram escolhidas aleatoriamente para receberem a suplementação alimentar, enquanto às demais não foi fornecida qualquer suplementação.

O fornecimento da suplementação energéticoprotéica foi iniciado no mês de maio de 2003, visando à obtenção de uma alta população de operárias adultas e nutridas suficientemente para iniciar a coleta de néctar e armazenagem de mel já na primeira florada significativa que ocorre durante o inverno (mês de julho), a florada da bracatinga. A suplementação, que se prolongou até dezembro do mesmo ano, foi constituída por uma dieta energético-protéica, composta por 1 litro de xarope de açúcar invertido e $20 \mathrm{ml}$ de Promotor $\mathrm{L}^{\circledR}$ (Tabela 1), que consiste de um suplemento protéico-vitamínico largamente utilizado pelos apicultores da região do estudo. A dieta foi fornecida em alimentadores do tipo Boardman, na freqüência de 1 litro/semana.
TABELA 1: Composição do composto protéico-vitamínico (Promotor $\mathrm{L}^{\circledR}$ ) utilizado na composição da dieta de suplementação alimentar de colméias de Apis mellifera.

\begin{tabular}{|c|c|}
\hline COMPONENTE & QUANTIDADE \\
\hline Vitamina A & 10.000.000UI \\
\hline Vitamina $\mathrm{D}_{3}$ & $2.000 .000 \mathrm{UI}$ \\
\hline Menadiona Sod. Bisulfito (Vit $\mathrm{K}_{2}$ ) & $500 \mathrm{mg}$ \\
\hline Nicotinamida & $16,250 \mathrm{~g}$ \\
\hline D. Pantenol & $7.500 \mathrm{~g}$ \\
\hline Tiamina HCL (Vit $\left.\mathrm{B}_{1}\right)$ & $1,750 \mathrm{~g}$ \\
\hline Riboflavina 5 lost. Sódico $\left(\right.$ Vit $\left.\mathrm{B}_{2}\right)$ & $2,500 \mathrm{~g}$ \\
\hline Piridoxina HCL $\left(\right.$ Vit $\left.\mathrm{B}_{6}\right)$ & $1,125 \mathrm{~g}$ \\
\hline Vitamina $\mathrm{B}_{12}$ & $1,250 \mathrm{mcg}$ \\
\hline Pangamato sódico (Vit $\mathrm{B}_{15}$ & $0,500 \mathrm{mg}$ \\
\hline Biotina & $1.000 \mathrm{mcg}$ \\
\hline Inositol & $2,500 \mathrm{~g}$ \\
\hline Alanina & $11,5 \mathrm{~g}$ \\
\hline Arginina & $6,1 \mathrm{~g}$ \\
\hline Ácido aspártico & $9,5 \mathrm{~g}$ \\
\hline Fenilalanina & $5,5 \mathrm{~g}$ \\
\hline Cistina & $2,1 \mathrm{~g}$ \\
\hline Ácido glutâmico & $21,5 \mathrm{~g}$ \\
\hline Glicina & $9,6 \mathrm{~g}$ \\
\hline Histidina & $4,7 \mathrm{~g}$ \\
\hline Hidroxiprolina & Traços \\
\hline Isoleucina & $6,0 \mathrm{~g}$ \\
\hline Leucina & $12,5 \mathrm{~g}$ \\
\hline Lisina & $9,5 \mathrm{~g}$ \\
\hline Metionina & $2,2 \mathrm{~g}$ \\
\hline Prolina & $9,5 \mathrm{~g}$ \\
\hline Serina & $7,0 \mathrm{~g}$ \\
\hline Treonina & $5,0 \mathrm{~g}$ \\
\hline Triptofano & $2,0 \mathrm{~g}$ \\
\hline Tirosina & $5,3 \mathrm{~g}$ \\
\hline Valina & $5,2 \mathrm{~g}$ \\
\hline Enzimas & Traços \\
\hline $\begin{array}{l}\text { Veículo líquido, solubilizantes e } \\
\text { estabilizantes c.s.p }\end{array}$ & $1.000 \mathrm{ml}$ \\
\hline
\end{tabular}

Fonte: Laboratórios Calier S.A.

Quando necessário, efetuou-se o manejo dos favos dentro das colméias e acrescentou-se material adicional para postura e armazenagem de alimento. Foram mensuradas as áreas de ovo e larva, as áreas de pupa, as áreas de pólen e as de mel de todos os favos das colméias com o auxílio de um quadro quadriculado com área conhecida. $\mathrm{O}$ quadro foi colocado dentro de um suporte, cujas laterais possuem arames esticados, formando quadrados de $2 \times 2 \mathrm{~cm}\left(4 \mathrm{~cm}^{2}\right)$ e, anotadas, 
separadamente,as mensurações das áreas citadas em $\mathrm{cm}^{2}$. Este procedimento foi utilizado para os dois lados do quadro. Contou-se, os quadriculados que continham cada variável analisada e determinou-se a área total. A metodologia adotada foi adaptada de Al-Tikrity et al. (1971, apud Funari et al., 2003). O delineamento experimental utilizado foi o inteiramente casualizado.

Utilizou-se o software GLIM para os procedimentos estatísticos. Os dados obtidos para as variáveis mensuradas foram submetidos à análise de covariância, usando-se modelos lineares generalizados com distribuição normal de erros. Assumiu-se o tempo (em dias) como variável independente e as médias dos tratamentos foram comparadas pelo teste $\mathrm{F}$, através de contraste ortogonal, com 5\% de significância (Crawley, 1993). O tempo zero correspondeu ao início do período de suplementação alimentar ( $2^{\mathrm{a}}$ quinzena de maio), efetuando-se avaliações aos 30, 90, 120 e 180 dias após, as quais corresponderam aos meses de junho, agosto, setembro e dezembro, respectivamente.

\section{Resultados e Discussão}

Verificou-se diferença significativa entre os tratamentos, as colméias que receberam a dieta suplementar apresentaram maiores áreas de ovo e larva, pupa, mel e de pólen. Entretanto, Lengler et al. (2000), testando diferentes fontes protéicas na alimentação de colméias de $A$. mellifera no período de maio a agosto, no município de Santa Maria/RS, não encontraram diferenças entre os tratamentos para as variáveis áreas de mel, pólen, ovo e larva e pupa. Costa et al. (2002), ao compararem colméias que receberam rações formulada e comercial, ambas com $35 \%$ de proteína, com colméias que não receberam nenhum tipo de suplementação, no período de setembro de 2000 a agosto de 2001, também não encontraram diferenças para as áreas com ovos, larvas e pupas e para as áreas com alimento (pólen e mel).

Os menores valores para área de mel foram obtidos entre junho e agosto, para ambos os tratamentos, contudo, as colméias não suplementadas apresentaram valores inferiores em relação àquelas que receberam suplementação neste período (Figura 1). Os resultados se assemelham aos encontrados por Alves et al. (1997), os quais observaram os menores valores para área de mel entre julho e agosto, embora não tenham encontrado diferença entre as colméias de A. mellifera com e sem suplementação protéica. A partir de agosto a área de mel começou a aumentar, sendo que as colméias com alimentação suplementar apresentaram um crescimento mais acentuado do que aquelas não suplementadas, o que se estendeu por todo o período de maior floração na região.

A área de pólen das colméias não suplementadas apresentou-se maior a partir de junho, enquanto as colméias suplementadas apresentaram maior armazenamento de pólen apenas no período de maio a julho (Figura 2), época em que a disponibilidade deste na natureza era menor e as condições climáticas eram menos propícias para a sua coleta e o desenvolvimento das colméias. Alves et al. (1997), ao verificarem o efeito da suplementação protéica sobre o desenvolvimento de colméias de $A$. mellifera, também constataram que a área de pólen foi menor nas colméias que receberam alimento protéico em relação à testemunha (colméias alimentadas com xarope de açúcar 50\%). A maior disponibilidade de alimento protéico nas colméias suplementadas auxiliou no suprimento das necessidades de proteína e energia requeridas para a manutenção da colméia, reduzindo o armazenamento do pólen.

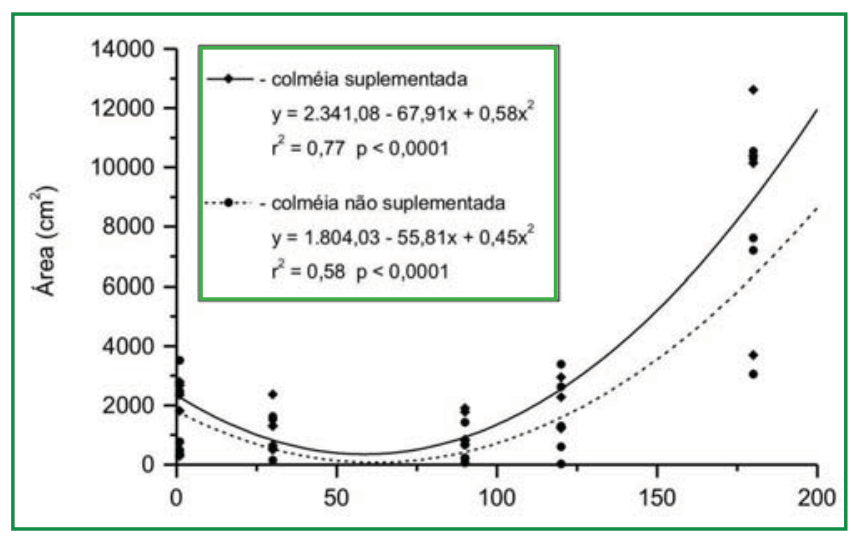

FIGURA 1: Área de mel de colméias de Apis mellifera suplementadas ou não com alimento energético-protéico, no período de maio a dezembro de 2003, em Ituporanga - SC.

A área de ovo e larva das colméias suplementadas apresentou-se maior do que a das não suplementadas apenas a partir do final de agosto (Figura 3). O 
significativo aumento da postura das rainhas nas colméias suplementadas a partir deste período coincide com o maior fluxo de néctar que ocorre na região (Salomé, 2002), estimulando-as à postura. No mês de agosto, o final da florada da bracatinga sobrepõe-se ao início da florada do vassourão-branco (Piptocarpha angustifolia Dusen) e dos citros, e no mês de setembro ocorre o florescimento do vassourão-preto (Piptocarpha cf. tomentosa Baker), da vassoura-branca (Baccharis cf. dracunculifolia DC), da vassoura (Eupatorium sp.), da guabiroba e do pessegueiro-bravo (Salomé, 2002).

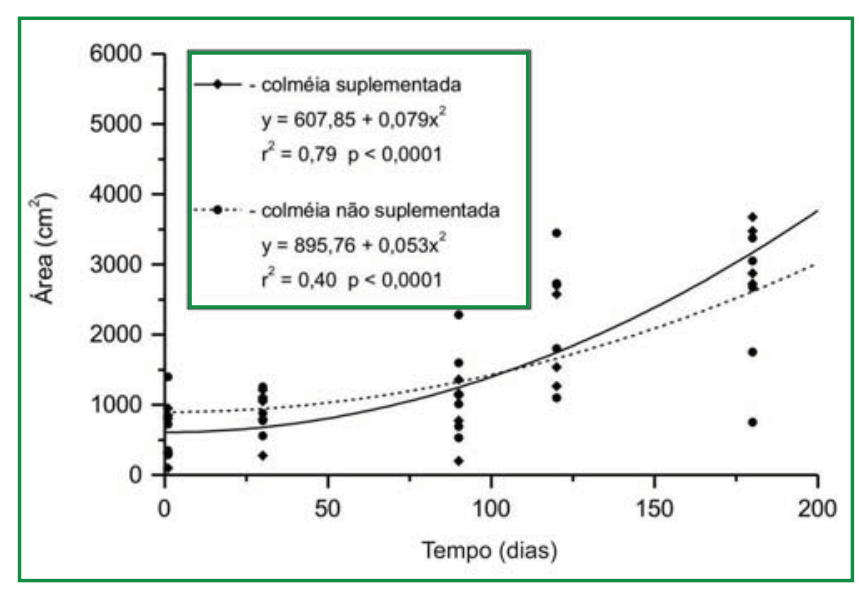

FIGURA 2: Área de pólen de colméias de Apis mellifera suplementadas ou não com alimento energéticoprotéico, no período de maio a dezembro de 2003, em Ituporanga $-\mathrm{SC}$

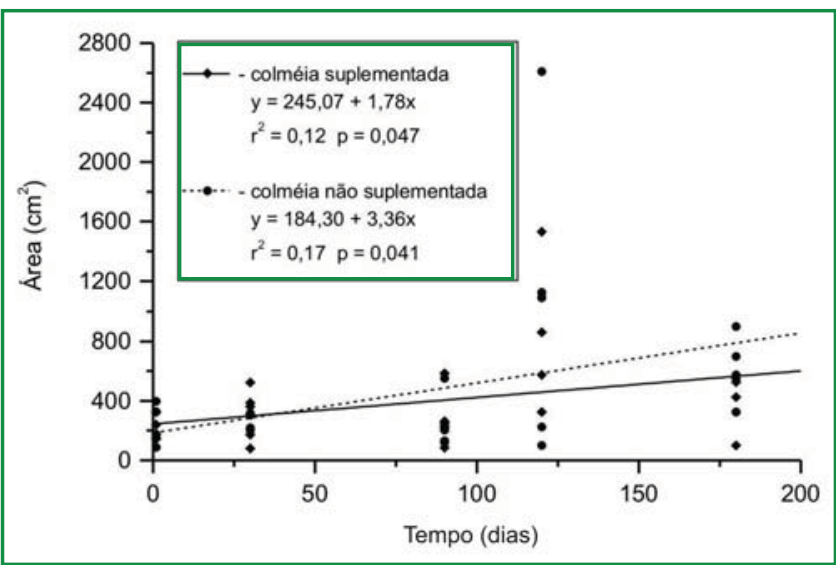

FIGURA 3: Área de ovos e larvas de colméias de Apis mellifera suplementadas ou não com alimento energéticoprotéico, no período de maio a dezembro de 2003, em Ituporanga-SC

O aumento na produção de ovos e larvas nas colméias suplementadas, constatado a partir do final de agosto (Figura 3), demonstra que estas não se tornaram maduras ou estabilizadas antes do fluxo de néctar, e portanto não antecipando o desenvolvimento da colméia com a finalidade de antecipar a produção de mel. Esperava-se que a alimentação suplementar energético-protéica antecipasse a postura das colméias, para que estas estivessem populosas e nutridas o suficiente para a realização das coletas e armazenamento de mel, aproveitando ao máximo o fluxo de néctar da primavera. A alimentação suplementar protéica fornecida, neste caso, pode ter suprido as necessidades de proteína e energia requeridas à manutenção da colméia, auxiliando no desenvolvimento da mesma, pois não houve necessidade de ir à busca de alimento, mas não antecipou a produção de mel.

Analisando-se a área de pupa, verificou-se que as colméias que não receberam suplementação alimentar apresentaram maior área ao longo do período, com tendência a igualar-se às suplementadas (Figura 4), devido ao aumento da área de ovos e larvas a partir do final de agosto. Portanto, a suplementação alimentar, neste caso favoreceu o desenvolvimento das larvas no mesmo período de máxima floração na natureza.

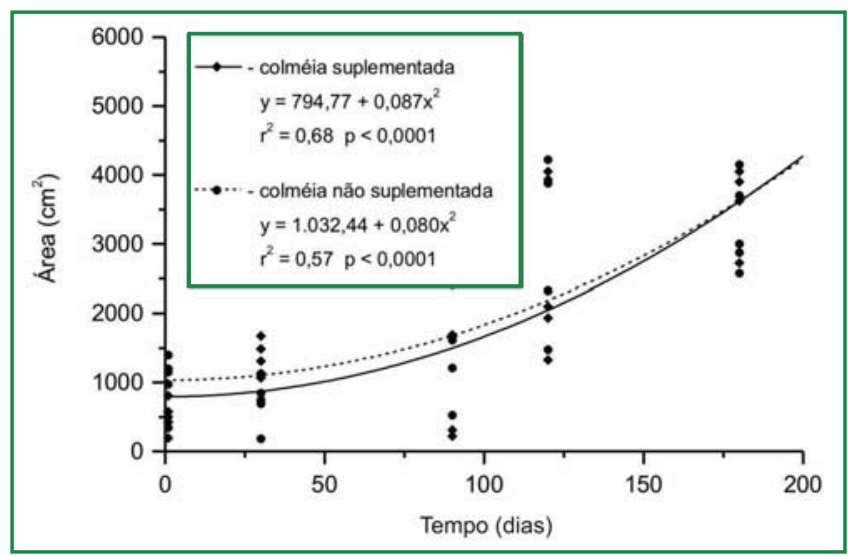

FIGURA 4: Área de pupas de colméias de Apis mellifera suplementadas ou não com alimento energéticoprotéico, no período de maio a dezembro de 2003, em Ituporanga-SC.

A suplementação energético-protéica interferiu no armazenamento de alimento (mel e pólen) pelas abelhas, sendo que as colméias suplementadas armazenaram maior quantidade de mel e menos pólen do que as não suplementadas. Talvez a oferta do suplemento tenha 
determinado uma menor coleta e reserva de nutrientes na forma de pólen. No entanto, este tipo de suplementação não proporcionou a antecipação do desenvolvimento e da produção das colméias.

As condições climáticas numa região podem variar a cada ano e serão determinantes nos efeitos da suplementação alimentar, sendo seus efeitos mais evidentes e positivos no desenvolvimento das colméias num ano com pouca floração.

\section{Referências}

Alves, M. L. T. M. F.; Silva, E. C. A.; Moreti, A. C. C. C.; Silva, R. M. B. 1997. Efeito da suplementação protéica sobre a quantidade de pólen coletado e o desenvolvimento de colônias de abelhas africanizadas (Apis mellifera). Boletim da Indústria Animal, 54 (1): 58-89.

Chaud Netto, J. 1992. Abandono do ninho: Uma estratégia de sobrevivência das abelhas do gênero Apis. Naturália. Anais do Encontro Brasileiro sobre Biologia de Abelhas e outros Insetos Sociais, Rio Claro e Ribeirão Preto, Brasil, p.101-105.
Costa, F. M.; Toledo, V. A. A.; Albuquerque, K. P.; Hashimoto, J. H.; Attencia, V. M.; Chiari, W. C.; Ruvolo-Takasusuki, M. C. C.; Furlan, A. C. 2002. Utilização de rações formulada e comercial para colônias de Apis mellifera africanizadas. Anais eletrônicos do $5^{\circ}$ Encontro sobre Abelhas, Ribeirão Preto, Brasil, CD-ROM.

Crawley, M. J. 1993. GLIM for ecologists. Methods in ecology. Blackwell, Oxford, UK, 379pp.

Doull, K. M. 1975. Pollen supplements, III. Making effective use of supplementary feeding. American Bee Journal, 155 (3): 88-89.

Johansson, T. S. K.; Johansson, M. P. 1977. Feeding honeybees with pollen and substitutes. Bee World, 58: 105-118.

Funari, S. R. C.; Rocha, H. C.; Sforcin, J. M.; Curi, P. R.; Funari, A. R.; Orsi, M. R. O. 2003. Efeitos da coleta de pólen no desenvolvimento de colônias e na composição bromatológica de pupas de Apis mellifera L. Archivos Latinoamericanos de Producción Animal, 11 (2): 80-86.

Lengler, S.; Charão, L.; Kiefer, C. 2000. Efeito de diferentes fontes protéicas no desenvolvimento intrínseco e produção de mel em colméias de abelhas. Anais eletrônicos do Congresso Brasileiro de Apicultura, Florianópolis, Brasil, CD-ROM.

Salomé, J. A. 2002. Levantamento e fenologia de plantas apícolas do Estado de Santa Catarina. Dissertação de Mestrado, Universidade Federal de Santa Catarina, Brasil, 112pp.

Silva, E. C. A.; Silva, R. M. B. 1985. Alimentação estimulante de abelhas suplementadas com proteína e seu efeito na produção de mel. Boletim da Indústria Animal, 42 (2): 255-263. 